\title{
RASGRF2 wt Allele
}

National Cancer Institute

\section{Source}

National Cancer Institute. RASGRF2 wt Allele. NCI Thesaurus. Code C52915.

Human RASGRF2 wild type allele is located in the vicinity of $5 q 13$ and is approximately 269 $\mathrm{kb}$ in length. This allele, which encodes Ras-specific guanine nucleotide-releasing factor 2 protein, is involved in the progression of Ras-mediated signaling. 